\title{
A transplantable tumor model allowing investigation of NY-BR-1-specific T cell responses in HLA-DRB1*0401 transgenic mice
}

Krishna Das ${ }^{1,2,3}$, David Eisel ${ }^{1,3,4}$, Mathias Vormehr ${ }^{4,5}$, Karin Müller-Decker ${ }^{6}$, Adriane Hommertgen ${ }^{1,7}$, Dirk Jäger ${ }^{8,9}$, Inka Zörnig ${ }^{9}$, Markus Feuerer ${ }^{10}$, Annette Kopp-Schneider ${ }^{11}$, Wolfram Osen ${ }^{1}$ and Stefan B. Eichmüller ${ }^{1 *}$ (D)

\begin{abstract}
Background: NY-BR-1 has been described as a breast cancer associated differentiation antigen with intrinsic immunogenicity giving rise to endogenous $T$ and $B$ cell responses. The current study presents the first murine tumor model allowing functional investigation of NY-BR-1-specific immune responses in vivo.

Methods: A NY-BR-1 expressing tumor model was established in DR4tg mice based on heterotopic transplantation of stable transfectant clones derived from the murine $\mathrm{H} 2$ compatible breast cancer cell line EO771. Composition and phenotype of tumor infiltrating immune cells were analyzed by qPCR and FACS. MHC I binding affinity of candidate CTL epitopes predicted in silico was determined by FACS using the mutant cell line RMA-S. Frequencies of NY-BR-1 specific CTLs among splenocytes of immunized mice were quantified by FACS with an epitope loaded $D^{\mathrm{b}}$-dextramer. Functional CTL activity was determined by IFNy catch or IFNY ELISpot assays and statistical analysis was done applying the Mann Whitney test. Tumor protection experiments were performed by immunization of DR4tg mice with replication deficient recombinant adenovirus followed by s.c. challenge with NY-BR-1 expressing breast cancer cells.

Results: Our results show spontaneous accumulation of $\mathrm{CD} 8^{+} \mathrm{T}$ cells and $\mathrm{F} 4 / 80^{+}$myeloid cells preferentially in NY-BR-1 expressing tumors. Upon NY-BR-1-specific immunization experiments combined with in silico prediction and in vitro

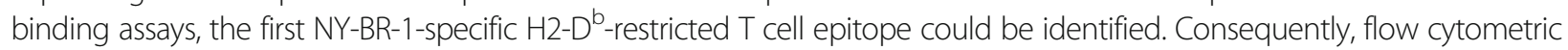
analysis with fluorochrome conjugated multimers showed enhanced frequencies of $\mathrm{CD} 8^{+} \mathrm{T}$ cells specific for the newly identified epitope in spleens of immunized mice. Moreover, immunization with Ad.NY-BR-1 resulted in partial protection against outgrowth of NY-BR-1 expressing tumors and promoted intratumoral accumulation of macrophages.

Conclusion: This study introduces the first $\mathrm{H2}-\mathrm{D}^{\mathrm{b}}$-resctricted $\mathrm{CD} 8^{+} \mathrm{T}$ cell epitope-specific for the human breast cancer associated tumor antigen NY-BR-1. Our novel, partially humanized tumor model enables investigation of the interplay between HLA-DR4-restricted T cell responses and CTLs within their joint attack of NY-BR-1 expressing tumors.
\end{abstract}

Keywords: NY-BR-1, Differentiation antigen, CTL epitope, HLA transgenic mice

\footnotetext{
*Correspondence: s.eichmueller@dkfz.de

'Research Group GMP \& T Cell Therapy, German Cancer Research Center

(DKFZ), Heidelberg, Germany

Full list of author information is available at the end of the article
}

(c) The Author(s). 2019 Open Access This article is distributed under the terms of the Creative Commons Attribution 4.0 International License (http://creativecommons.org/licenses/by/4.0/), which permits unrestricted use, distribution, and reproduction in any medium, provided you give appropriate credit to the original author(s) and the source, provide a link to the Creative Commons license, and indicate if changes were made. The Creative Commons Public Domain Dedication waiver (http://creativecommons.org/publicdomain/zero/1.0/) applies to the data made available in this article, unless otherwise stated. 


\section{Background}

Although improved diagnostic tools and advanced therapy approaches have succeeded in reducing the standardized cancer mortality rate of breast cancer over the last decades, this tumor entity still remains the second most frequent cancer type among women, predicted to cause more than 93,000 deaths in the European Union in the year 2020 [1]. New treatment strategies are thus needed in order to further improve the clinical outcome of breast cancer patients, particularly since standard therapy approaches are often associated with severe side effects [2] or can even induce therapeutic resistance [3]. At this point, immunological treatment strategies exploiting the activity of autologous tumor-reactive $\mathrm{T}$ cells might offer an attractive complement or alternative to classical treatment regimens. In fact, adoptive $\mathrm{T}$ cell therapy, particularly in combination with checkpoint inhibitors, has yielded promising results in various clinical settings $[4,5]$. The concept of this therapeutic approach relies on the notion that activated tumor antigen-specific $\mathrm{T}$ cells selectively attack tumor cells leaving healthy tissue unaffected. However, to fulfill this aim, target antigens need to be identified that are selectively expressed by the tumor, but absent or underrepresented in normal tissue. The breast cancer associated differentiation antigen NY-BR-1 meets this criterion as it was found to be strongly overexpressed in breast tumors originating from ductal epithelial cells [6].

Interestingly, NY-BR-1 is characterized by marked intrinsic immunogenicity as both antibody [7] and cytotoxic $\mathrm{T}$ cell (CTL) responses [8, 9] have been detected in breast cancer patients. CTLs recognize short peptides that are presented by MHC I molecules on the surface of the target cell, resulting in apoptosis induction within the recognized cell $[10,11]$. Thus, most $\mathrm{T}$ cell based immunotherapy approaches have aimed at the induction of tumor-reactive $\mathrm{CD}^{+} \mathrm{T}$ cells, considered as ultimate effector cells due to their capacity of direct tumor cell killing. On the other hand, tumor antigen-specific $\mathrm{CD}^{+}{ }^{+} \mathrm{T}$ cells have been demonstrated to represent essential contributors of CTL-mediated tumor attack [12], implying that epitopes presented by MHC II molecules to $\mathrm{CD}_{4}^{+}$ $\mathrm{T}$ cells are of central importance in tumor immune surveillance [13]. In a previous study we thus used HLADR4 transgenic (HLA-DR4tg) mice to identify the first NY-BR-1-specific CD4 ${ }^{+} \mathrm{T}$ cell epitopes that might help to induce and monitor tumor antigen-specific $\mathrm{T}$ cell responses in breast cancer patients [14]. However, a NYBR-1 expressing tumor model allowing investigation of NY-BR-1-specific $\mathrm{T}$ cell responses in vivo has been lacking so far. We thus set out to establish such a tumor model based on ectopic transplantation of a NY-BR-1 expressing mouse mammary carcinoma cell line onto HLA-DR4tg mice. Moreover, we introduce the first NY-
BR-1-specific $\mathrm{H} 2{ }^{\mathrm{b}}$-restricted CTL epitope and describe the composition of tumor infiltrating immune cell populations with particular focus on NY-BR-1-specific CD4 ${ }^{+}$ T cells and HLA-DR4 positive tumor-associated macrophages. The NY-BR-1 expressing tumor model presented here, offers a valuable tool to investigate immune responses against NY-BR-1 expressing tumor cells in vivo.

\section{Methods \\ Cell lines}

Both murine tumor cell lines used were of C57BL/6 origin $\left(\mathrm{H} 2^{\mathrm{b}}\right)$. The mammary adenocarcinoma cell line EO771 was purchased from TEBU-Bio (Offenbach, Germany) and RMA-S cells (a Rauscher virus induced T lymphoma) were kindly provided by Günter Hämmerling, DKFZ Heidelberg, Germany. RMA-S cells were propagated in complete RPMI medium containing RPMI 1640 supplemented with Glutamax (Life technologies / Thermo Fisher), 10\% FCS (Biochrom, Berlin, Germany), and $1 \%$ penicillin-streptomycin (Life technologies / Thermo Fisher). EO771 cells were cultured in complete RPMI medium containing $1 \mathrm{mM}$ HEPES buffer (SigmaAldrich, Saint Louis, MO).

\section{HLA-DR4-transgenic mice}

B6.129S2-H2-Ab1 ${ }^{\text {tm1Gru }}$ Tg (HLA-DRA/H2-Ea,HLADRB1*0401/H2-Eb)1Kito mice expressing a chimeric HLADRA-IE ${ }^{\mathrm{d}} \alpha /$ HLA-DRB1*0401-IE ${ }^{\mathrm{d}} \beta$ molecule on a $\mathrm{H} 2-\mathrm{IA}^{0 / 0}$ background [15] (designated as HLA-DR4tg mice throughout this paper) were obtained from Taconic (Cologne, Germany) and further bred in the Centralized Laboratory Animal Facilities of the German Cancer Research Center Heidelberg. Animals were group housed in standard individually ventilated cages with wood chip embedding (LTE E-001, ABEDD, Vienna, Austria), nesting material, ad libitum diet (autoclaved mouse/rat housing diet 3437, PROVIMI KLIBA AG, Kaiseraugst, Switzerland) and autoclaved tap water.

In accordance with the Appendix A of des European Convention for the Protection of Vertebrate Animals used for Experimental and Other Scientific Purposes from 18th March 1986 room temperature and relative humidity were adjusted to $22.0 \pm 2.0{ }^{\circ} \mathrm{C}$ and $55.0 \pm 10.0 \%$, respectively. All animals were housed under strict specified pathogen-free (SPF) conditions according to the recommendations of the FELASA. The light/dark (L/D) cycle was adjusted to $14 \mathrm{~h}$ lights on and $10 \mathrm{~h}$ lights off with the beginning of the light and dark period set at 6.00 am and $8.00 \mathrm{pm}$, respectively.

All animal experimentation performed in this study was conducted according to the national guidelines and was reviewed and confirmed by the institutional review board/ethics committee of the German Cancer Research 
Center, Heidelberg). The animal experiments were finally approved by the responsible national authority, which is the Regional Authority of Karlsruhe (Germany; official approval ID 35-9158.81/G172-12).

Sample size calculation was performed by the Biostatistics Department of the DKFZ following standard procedures. Mice were randomized to the different treatment groups. Treatment was performed in random order. Health status of mice has regularly been tested by the Animal Core Facility. Only animals with approved health status were included in the experiments.

\section{Generation of stable NY-BR-1 expressing transfectant clones}

EO771 cells were transfected with $1.2 \mu \mathrm{g}$ linearized pcDNA3.1(-)zeo-NY-BR-1 expression vector generated upon cloning of the NY-BR-1 encoding cDNA fragment from pcDNA3.1-NY-BR-1 (kindly provided by I. Zörnig) into pcDNA3.1(-)zeo (Invitrogen / ThermoFisher, Waltham, MA) via Kpn1/Not1 digestion. After selection with Zeocin $(400 \mu \mathrm{g} / \mathrm{mL})$, individual clones were raised by limiting dilution.

\section{Western blot analysis}

Cellular proteins $(15-50 \mu \mathrm{g})$ of heat denatured cell lysates were separated by SDS PAGE using a $10 \%$ polyacrylamide gel, followed by electro-transfer onto nitrocellulose membranes. Membranes were incubated overnight at $4{ }^{\circ} \mathrm{C}$ with a murine monoclonal antibody (clone\#2, diluted 1:1000) specific for NY-BR-1 in $0.5 \%$ non-fat milk in Tris buffered saline containing $0.1 \%$ Tween 20 (TBS-T buffer) on a shaking platform. Beta actin was detected using a monoclonal antibody (MP Biomedical, Solon, $\mathrm{OH}$ ) diluted 1:10,000 in 0.5\% non-fat milk in TBS-T buffer. Next, membranes were washed and incubated with horseradish peroxidase- conjugated secondary antibody (Santa Cruz Biotechnology, Santa Cruz, TX) diluted 1:10,000 in 0.5\% non-fat milk in TBS$\mathrm{T}$ buffer for $1 \mathrm{~h}$ at room temperature. Protein signals were detected using the enhanced chemiluminescence system (GE Healthcare, Munich, Germany) either by exposing blots to an X-ray film or by a CCD camera.

\section{Peptide binding assay}

Peptide binding assays were performed as described [16]. Briefly, $2 \times 10^{5}$ RMA-S cells were incubated overnight with graded peptide concentrations in round bottom microtiter plates followed by indirect immunoflourescence staining using supernatants of hybridoma E3-25 or $\mathrm{B} 22.249$ specific for $\mathrm{H} 2-\mathrm{K}^{\mathrm{b}}$ or $\mathrm{H} 2-\mathrm{D}^{\mathrm{b}}$ molecules, respectively. All hybridomas were kindly provided by $G$. Hämmerling.

\section{IFNץ ELISPOT assay}

IFN $\gamma$ secretion of splenocytes from immunized mice or of established $\mathrm{T}$ cell lines was analyzed by IFNY ELSIPOT assay as described previously [17], except that $5 \mu \mathrm{g} /$ $\mathrm{mL}$ anti-mouse IFNy capture antibody were used for membrane coating. ELISPOT results were analyzed using two ELISPOT reader devices from AID (Strassberg, Germany) or C.T.L. (Cleveland, $\mathrm{OH}$ ), respectively. Statistical analysis was performed using Mann Whitney test.

\section{IFN $\gamma$ catch assay}

Flow cytometric detection of IFNy secreting $\mathrm{T}$ cell subpopulations was performed using the Mouse IFN- $\gamma$ Secretion Assay - Detection Kit (Miltenyi Biotec $\mathrm{GmbH}$, Gladbach, Germany) according to the optimized manufacturer's protocol. Briefly, $2 \times 10^{6}-2.5 \times 10^{6}$ spleen cells were stimulated overnight with $5 \mu \mathrm{g} / \mathrm{mL}$ peptide. Next day, cells were washed twice followed by incubation with IFN $\gamma$ catch reagent for $2-3 \mathrm{~h}$ at $37^{\circ} \mathrm{C}$ cells. Cells were then washed and stained with LIVE/DEAD ${ }^{\circ}$ Fixable Yellow Dead Cell Stain or LIVE/DEAD ${ }^{\circ}$ Fixable Blue Dead Cell Stain Kit (Invitrogen / Thermo Fisher) diluted 1: 1000 in PBS for $30 \mathrm{~min}$ at $4{ }^{\circ} \mathrm{C}$. Finally, cells were stained with fluorochrome-labelled anti-mouse CD4 antibody, anti-mouse CD8 antibody and anti-IFN- $\gamma$ PE (Miltenyi Biotec $\mathrm{GmbH}$, Gladbach, Germany). Data was acquired on a FACS Calibur1, FACS Canto II or LSR II and analyzed with FlowJo software. Statistical analysis was done using Mann Whitney test. Finally, cells were stained with fluorochrome-labelled anti-mouse CD4 antibody, antimouse CD8 antibody and anti-IFN- $\gamma$ PE (Miltenyi Biotec $\mathrm{GmbH}$, Gladbach, Germany). Data was acquired on a FACS Calibur1, FACS Canto II or LSR II and analyzed with FlowJo software. Statistical analysis was done using Mann Whitney test.

\section{Tumor growth experiments}

Harvested tumor cell lines were washed three times in PBS and adjusted to titers mentioned in the Results part. Tumor cells were suspended in PBS $(100 \mu \mathrm{L})$ and injected subcutaneously into the right hind flank of 6-10 week-old female HLA-DR4tg mice without anaesthesia. Tumor growth was monitored by caliper measurements twice per week. Mice were killed by $\mathrm{CO} 2$ intoxication 30 days after tumor cell injection or when tumors reached a size of 15 $\mathrm{mm}$ in diameter, respectively.

\section{Immunization with recombinant adenovirus}

Recombinant, replication-deficient adenovirus encoding NY-BR-1 (Ad.NY-BR-1) and the empty control virus (Ad.Control) were purchased from GeneCust (Dudelange, Luxembourg). Mice were injected (i.p.) with $5 \times$ $10^{8}$ plaque-forming units (pfu) Ad.NY-BR-1 or Ad. 
Control, respectively, and killed 14 days later by $\mathrm{CO} 2$ intoxication for splenectomy, unless otherwise indicated.

\section{Isolation of tumor infiltrating leukocytes}

Excised tumors were cut into small pieces followed by digestion with a mixture of Collagenase D $(0.5 \mathrm{mg} / \mathrm{mL})$ (Roche Diagnostics, Mannheim, Germany), DNAse I $(10 \mu \mathrm{g} / \mathrm{mL})$ (Sigma-Aldrich), TLCK inhibitor $(0.1 \mu \mathrm{g} / \mathrm{mL})$ (Sigma-Aldrich, Saint Louis, U.S) and HEPES buffer (10 $\mathrm{mM}$ ) (Sigma-Aldrich) in HBSS (Sigma-Aldrich) for $1 \mathrm{~h}$ at $37^{\circ} \mathrm{C}$. The tumor pieces were then passed through a $70 \mu \mathrm{m}$ cell strainer and the resulting suspension was centrifuged at $1400 \mathrm{rpm}$ for $10 \mathrm{~min}$. Cells were resuspended in $5 \mathrm{~mL}$ RPMI medium and separated by density gradient centrifugation (Lympholyte $\mathrm{M}$, Cedarlane Labs, Burlington, Canada). Leukocytes were harvested from the interphase and used for subsequent experiments. The pellet consisting of tumor cells was washed with PBS and used for RNA and protein isolation as required.

\section{Magnetic activated cell sorting (MACS) for positive selection}

Cytotoxic $\mathrm{T}$ cells and tumor-infiltrating myeloid cells were enriched by magnetic cell sorting using magnetic antibody-coated (CD8a- or CD11b-specific) microbeads and MS or LS columns, respectively, according to the manufacturer's instructions (Miltenyi Biotec).

\section{Dextramer staining}

Spleen cell suspensions prepared from immunized mice were adjusted to $1 \times 10^{6}$ cells $/ \mathrm{mL}$ and incubated with LIVE/DEAD ${ }^{\circ}$ Fixable Yellow Dead Cell Stain (Life Technologies / Thermo Fisher) diluted 1:1000 in PBS for 30 min at $4{ }^{\circ} \mathrm{C}$. After washing with PBS, cells were incubated with APC-labeled H2-D ${ }^{\mathrm{b}}$ dextramers (Immudex, Copenhagen, Denmark) loaded with NY-BR-1 $1_{1241-1249}$ or with Human Papilloma Virus (HPV) 16 E749-57, diluted as indicated in $60 \mu \mathrm{L}$ FACS buffer for $30 \mathrm{~min}$ at room temperature in the dark. Fluorochrome-labeled antibodies against CD3 (clone 17A2), CD8 (clone 53-6.7), CD4 (clone GK1.5) CD14 (clone Sa14-2) (all purchased from Biolegend, San Diego, CA), and the respective isotype controls were diluted 1:50 in $60 \mu \mathrm{L}$ FACS buffer and added to the cells without washing off the dextramers so that the final dilution of the antibodies was 100 -fold. Cells were incubated with the antibody mix at $4{ }^{\circ} \mathrm{C}$ for $30 \mathrm{~min}$. The cells were then washed and analyzed by flow cytometry for viable $\mathrm{CD}^{+} \mathrm{CD} 14^{-} \mathrm{CD} 8^{+}$dextramer ${ }^{+}$cells.

\section{Flow cytometry and cell sorting}

For flow cytometry, $1 \times 10^{6}$ cells were used per sample unless otherwise indicated. A mix of $0.05 \mathrm{mg} / \mathrm{mL}$ purified rat anti-mouse CD16/CD32 (BD Pharmingen), rat serum (GeneTex, Irvine, CA) and hamster serum
(Jackson Immunoresearch, West Grove, PA) was used to block Fc receptors on tumor infiltrating leukocytes for $20 \mathrm{~min}$ at $4{ }^{\circ} \mathrm{C}$. This step was omitted for tumor cell lines and splenocytes. The cells were then washed twice and $100 \mu \mathrm{L}$ of LIVE/DEAD ${ }^{\circledR}$ Fixable Yellow Dead Cell Stain or LIVE/DEAD ${ }^{\circ}$ Fixable Blue Dead Cell Stain Kit, for UV excitation (Life technologies / Thermo Fisher) diluted 1:1000 in PBS was added. After incubation for 30 min at $4{ }^{\circ} \mathrm{C}$, washed cells were stained with antibodies (or isotype controls) listed in Additional file 1: Table S1. After incubation for $1 \mathrm{~h}$ at $4{ }^{\circ} \mathrm{C}$, cells were washed and resuspended in 200-400 $\mu \mathrm{L}$ FACS buffer for flow cytometric sorting or analysis, respectively. For intracellular cytokine staining, cells were incubated in $100 \mu \mathrm{L}$ fixation permeabilization solution (BD Biosciences, San Jose, CA) for $20 \mathrm{~min}$ at $4{ }^{\circ} \mathrm{C}$, followed by two washing steps using BD Perm/Wash buffer. Cells were then incubated for $1 \mathrm{~h}$ at $4{ }^{\circ} \mathrm{C}$ with $100 \mu \mathrm{L}$ BD Perm/Wash buffer containing antibodies or isotype controls, respectively, diluted 1 : 100. Finally, cells were resuspended in $200-400 \mu \mathrm{L}$ FACS buffer for analysis.

\section{Quantitative RT-PCR}

Gene expression analysis by standard qRT-PCR using SYBR green was performed for the analysis of the polarization status of tumor-associated macrophages. Primer sequences are listed in Additional file 1: Table S2.

\section{Results}

Generation of a NY-BR-1 expressing breast cancer cell line In order to establish an ectopic NY-BR-1 expressing tumor model in HLA-DR4tg mice we used the mammary carcinoma cell line EO771 derived from C57BL/6 mice, thus sharing a syngeneic $\mathrm{H} 2$ background with DR4tg mice $\left(\mathrm{H} 2^{\mathrm{b}}\right)$. EO771 cells were transfected with a NY-BR-1 encoding expression plasmid pcDNA3.1(-)zeo-NY-BR-1 and NY-BR-1 expression among the Zeocin selected bulk culture was verified by qRT-PCR and Western blot analysis (Additional file 1: Figure S1A, B). Subsequently, single transfectant clones were raised from the bulk culture by limiting dilution resulting in a panel of EO771-derived clones showing stable NY-BR-1 protein expression (Fig. 1a). The clones EONY\#9 and EONY\#17 were chosen for subsequent experiments. Since formation of necrotic tumors were observed upon orthotopic application of EONY\#9 and EONY\#17 in initial experiments (not shown), we decided to apply these clones ectopically by s.c. injection into the flank of the mice.

When tested for their growth kinetics in DR4tg mice, EONY\#9 and EONY\#17 showed different growth behavior compared to parental EO771 cells (Fig. 1b). Clone EONY\#9 showing strongest NY-BR-1 expression often failed to form tumors in DR4tg mice, whereas clone 


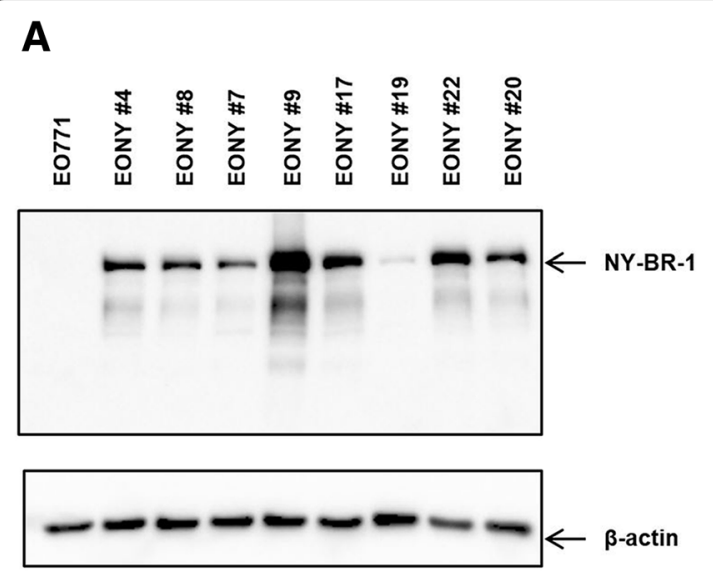

B

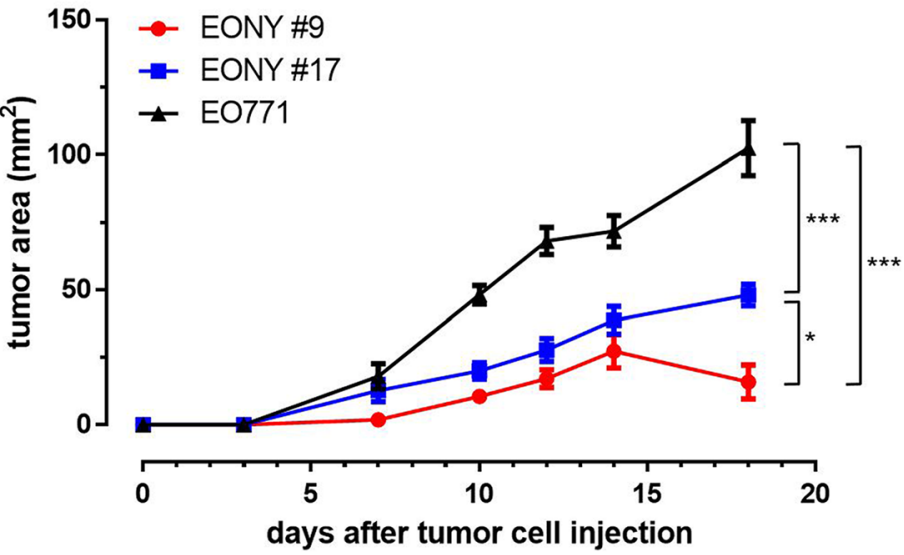

Fig. 1 Characterization of EO771/NY-BY-1 transfectant clones. EO771/NY-BR-1 transfectant clones generated by transfection of EO771 cells with a linearized plasmid pCDNA3.1-NY-BR-1 followed by limiting dilution were characterized for NY-BR-1 expression in vitro and the ability to form tumors in vivo. a NY-BR-1 protein expression $(159 \mathrm{kDa})$ in the selected clones was analyzed by Western blot. $\beta$-actin $(42 \mathrm{kDa})$ was used as a loading control. b HLA-DRB1*0401tg mice were injected s.c. on the right flank with $2 \times 10^{5}$ EO771, EONY \#9 or EONY \#17 cells and tumor growth was monitored for 18 days post cell injection. Error bars represent SEM $(n=10)$. Tumor area was measured and statistical analysis was performed using a mixed linear model with random intercept for animal. Difference between cell lines was highly significant $(p<0.0001)$; pairwise comparisons: ${ }^{* * *} p<0.0001 ;{ }^{*} p=0.0157$

EONY\#17 with moderate NY-BR-1 expression did still grow out, albeit at lower rate compared to parental EO771 cells. As no differences in the viability between these transfectant clones and parental EO771 cells were detected (Additional file 1: Figure S2), we concluded that NY-BR-1 expressed by the transfectant clones was immunogenic in DR4tg mice, thereby reducing outgrowth of NY-BR-1 expressing tumors. Indeed, we found significantly elevated frequencies of $\mathrm{CD}^{+} \mathrm{T}$ cells within infiltrates of tumors originating from EONY\#9, compared to tumors derived from parental EO771 cells (Fig. 2a left). Consequently the relative proportion of infiltrating $\mathrm{CD}^{+} \mathrm{T}$ cells was reduced in EONY\#9 tumors (Fig. 2a middle).

Moreover, the proportion of $\mathrm{CD}_{11 \mathrm{~b}}{ }^{+} \mathrm{F} 4 / 80^{+}$myeloid cells, referred to as tumor-associated macrophages (TAMs), showed a tendency of elevated frequency in NY-BR-1 expressing tumors comprising up to $70 \%$ of $\mathrm{CD} 45^{+}$leukocytes (Fig. 2a right). We further investigated the phenotype of these TAMs and found that EONY\#9 tumors, derived from the high expresser transfectant clone \#9 (Fig. 1a), contained less HLA-DR4-positive TAMs compared to tumors derived from clone EONY\#17 or from parental EO771 cells (Fig. 2b, left). However, the extent of HLA-DR4 surface expression on TAMs derived from NY-BR-1 expressing transfectant clone EONY \#9 exceeded HLA-DR4 surface expression of TAMs obtained from parental EO771 (Fig. 2c, left). Similarly, the frequency of iNOS producing TAMs with enhanced iNOS expression levels was significantly increased in TAMs from NY-BR-1 expressing tumors (Fig. 2b, c, middle). Focusing on CD206 as surface marker of M2-like TAMs [18] we observed that NY-BR1 expressing tumors were infiltrated by CD206-positive macrophages to a slightly though not significant greater extent, but the level of CD206 surface expression was lower on these cells compared to EO771-derived TAMs (Fig. 2b, c right). Gene expression analyses performed on $\mathrm{CD}_{11 \mathrm{~b}^{+}}$tumor infiltrating immune cells isolated from EONY\#17 tumors showed enhanced expression of the M1-like markers IL1ß, Cxcl9, IL6 and Nos2 (Fig. 3a). However, expression of Fizz1 and Arg1 representing classical M2-like markers was elevated as well (Fig. 3b). Notably, the proportional size of the respective TIL subpopulations accumulating within the tumors did not correlate with tumor size, except for $\mathrm{iNOS}^{+} \mathrm{TAMs}$, whose proportion declined with increasing tumor size (data not shown).

Thus, s.c. transplantation of $2 \times 10^{5}$ NY-BR-1 expressing EONY\#17 cells was sufficient to give rise to subcutaneous tumors containing elevated frequencies of $\mathrm{CD} 8^{+}$ $\mathrm{T}$ cells and of TAMs.

\section{Identification of a NY-BR-1-specific $\mathrm{H}_{2}-\mathrm{D}^{\mathrm{b}}$-restricted $\mathrm{CD} 8^{+}$ $T$ cell epitope in HLA-DR4tg mice}

Since $\mathrm{CD}^{+} \mathrm{T}$ cells are considered as primary effector cells in tumor immune surveillance along with the fact that this $\mathrm{T}$ cell subset was overrepresented in NY-BR-1 expressing tumors, we set out to identify NY-BR-1-specific $\mathrm{CD}^{+} \mathrm{T}$ cell epitopes that might be involved in 
A

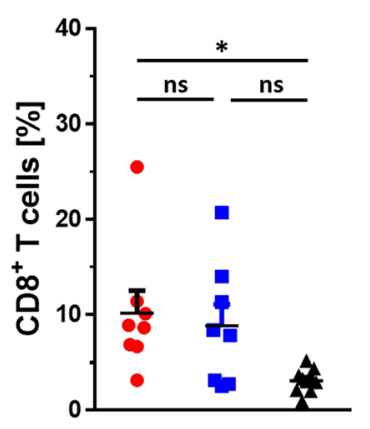

B

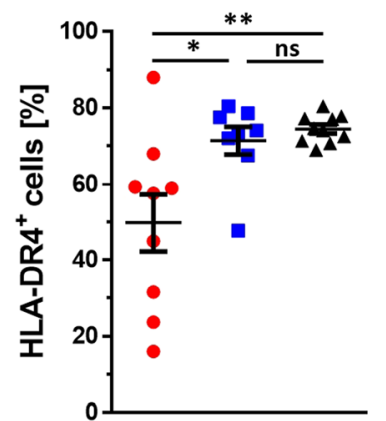

C

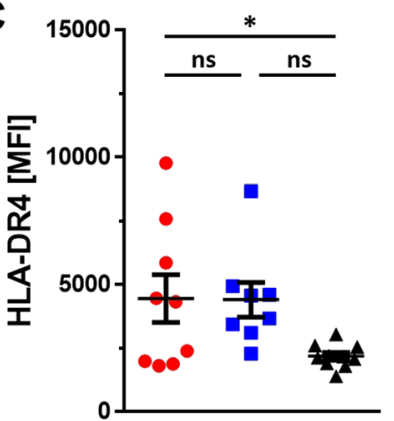

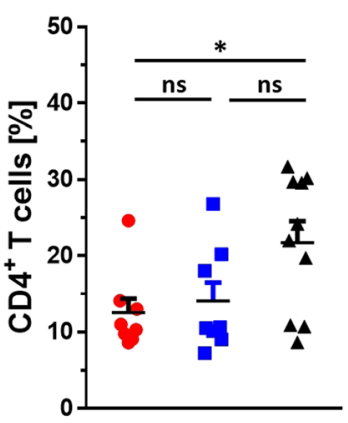
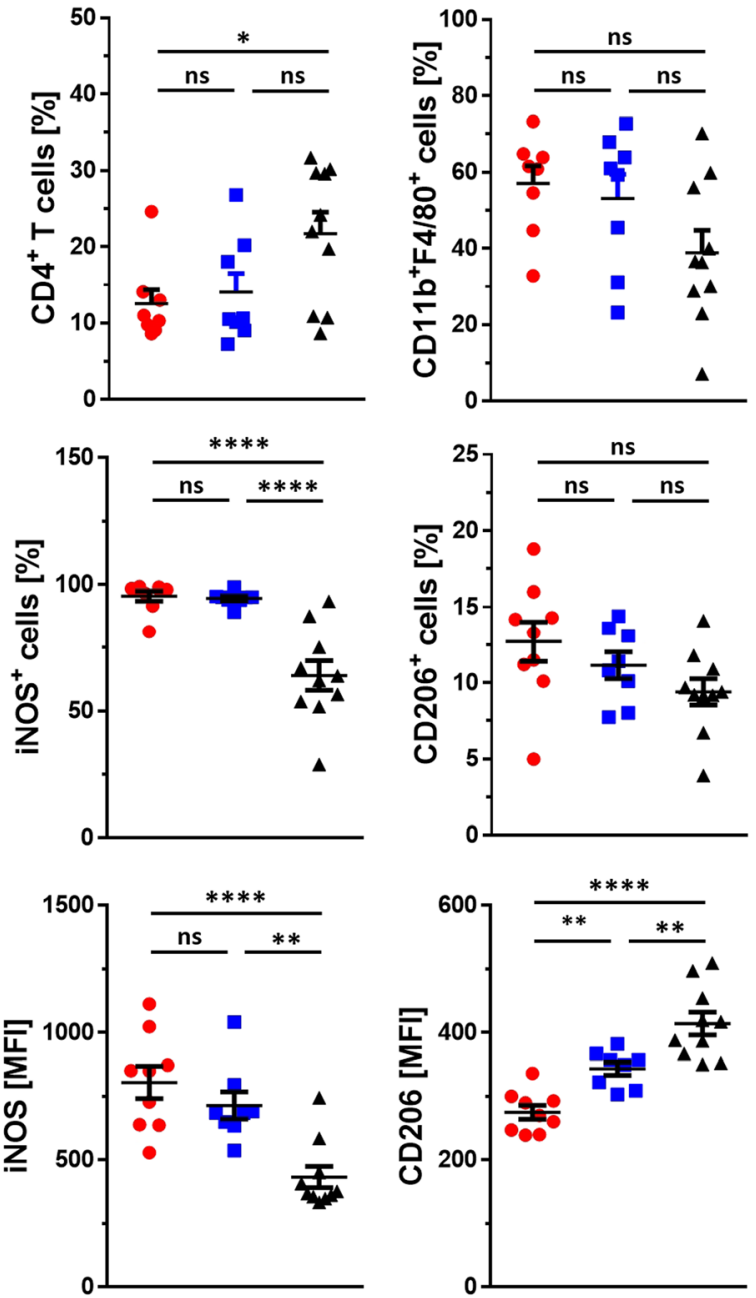

¿ E0771 tumors

Fig. 2 Characterization of tumor-infiltrating leukocytes in EO771 and EONY tumors. $2 \times 10^{5}$ EO771 cells, EONY\#9 cells or EONY\#17 cells were injected s.c. into the right flank of HLA-DRB1*0401tg mice $(n=10)$. Tumor-infiltrating leukocytes were isolated 20 days post cell implantation and analyzed by flow cytometry. a Percentage of $C D 8^{+} T$ cells, $C D 4^{+} T$ cells and CD11 b $\mathrm{b}^{+} 4 / 80^{+}$macrophages among CD45 ${ }^{+}$leukocytes is depicted for the different tumors. $\mathbf{b}$ The frequency of TAMs expressing M1-associated markers HLA-DR4 and iNOS or M2-associated marker CD206. c The corresponding surface expression levels (MFI) on the positive cells is presented. Error bars depict SEM and statistical analysis performed using One-way-ANOVA with Tukey's multiple comparisons (* $p \leq 0.05 ;{ }^{* *} p \leq 0.01 ; * * 0 \leq 0.001 ;{ }^{* * *} p \leq 0.0001$ )

CTL recognition of NY-BR-1 expressing tumor cells. Upon in silico analysis applying the SYFPEITHI data base [19] on epitope containing library peptides determined previously by us [14] we selected a panel of potential $\mathrm{H} 2-\mathrm{D}^{\mathrm{b}}$-restriced $\mathrm{T}$ cell epitopes with prediction scores greater than 23, arbitrarily set as cut off based on the scores of known CTL epitopes (Table 1). Thus, NYBR-1 ${ }_{25-33}$, NY-BR-1 ${ }_{460-468}$, NY-BR-1 $1092-1100$, and NYBR-1 1241-1249 were generated by Fmoc chemistry and used as synthetic candidate epitopes in peptide binding assays with RMA-S cells to evaluate their binding affinity for the H2-D ${ }^{\mathrm{b}}$ molecule. NY-BR-1 $1_{1241-1249}$ showed strong binding affinity to the H2- $\mathrm{D}^{\mathrm{b}}$ molecule, even exceeding the binding capacity observed with the E7-specific CTL epitope included as positive control. In contrast, NY-BR-1 $1_{1092-1100}$ showed only marginal binding capacity, and peptides NY-BR-1 $1_{25-33}$ and NY-BR$1_{460-468}$ completely failed to stabilize $\mathrm{H} 2-\mathrm{D}^{\mathrm{b}}$ surface expression (Fig. 4a). None of the peptides tested bound to the $\mathrm{H} 2-\mathrm{K}^{\mathrm{b}}$ molecule (Fig. $4 \mathrm{~b}$ ).

In order to determine which of the peptides tested above would represent natural epitopes in vivo recognized by $\mathrm{CD}^{+} \mathrm{T}$ cells, HLA-DR4tg mice were immunized with Ad.NY-BR-1 followed by functional ex vivo analysis of 

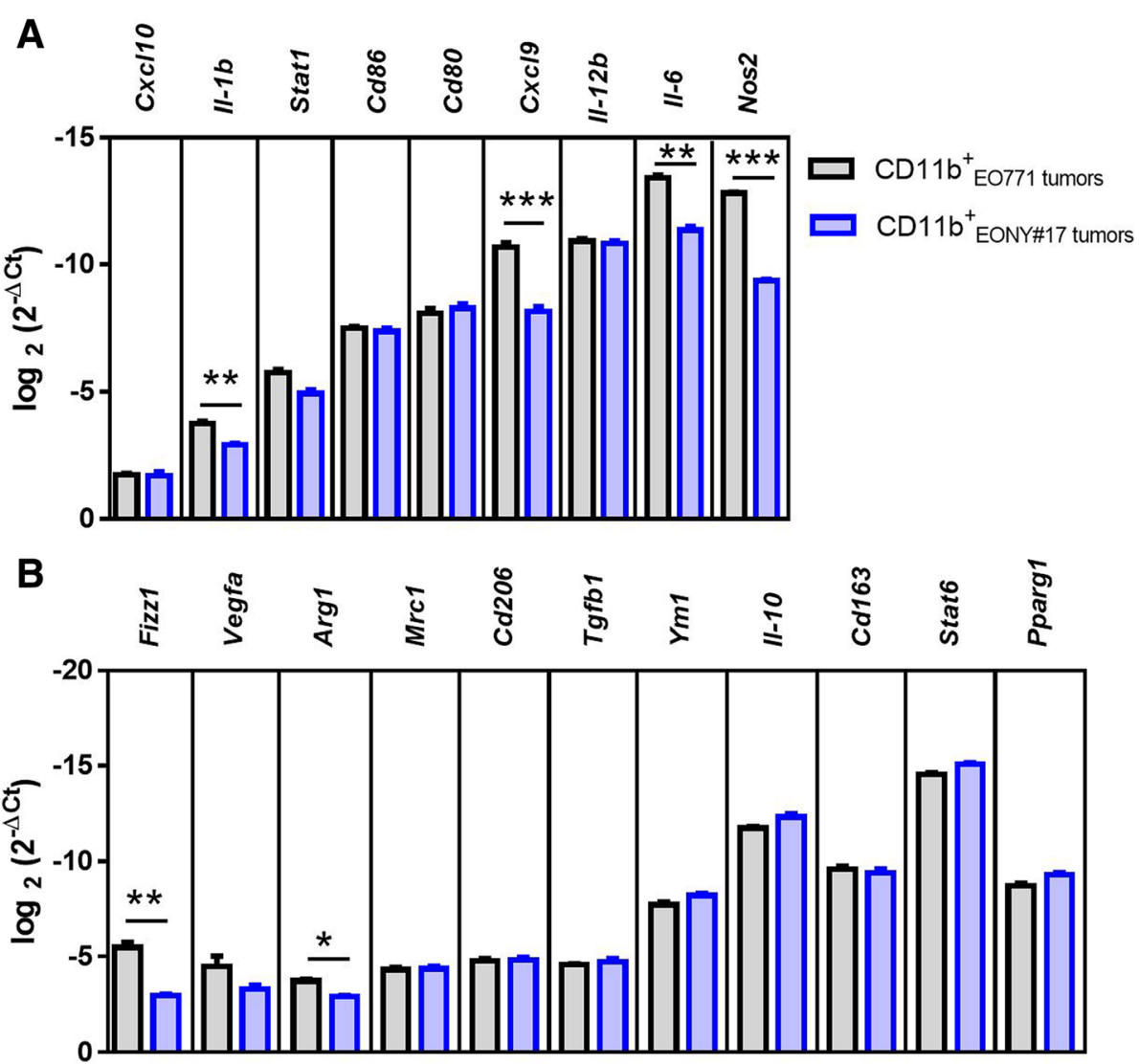

Fig. 3 Analysis of TAM polarization in EO771 and EONY\#17 tumors. Tumor infiltrating leukocytes isolated from EO771 and EONY\#17 tumors were enriched for $\mathrm{CD} 11 \mathrm{~b}^{+}$cells using anti-CD11b microbeads. The expression of various genes associated with a M2-like or $\mathbf{b}$ M1-like macrophages was analyzed in the isolated CD11 b cells by qRT-PCR. Log fold change of each gene normalized to the house-keeping gene is shown. Error bars represent SEM and statistical analysis was performed using Student's t test and Bonferoni-Holm adjusted $p$ values were calculated (* $p<0.05 ;{ }^{* *}$ $\left.p<0.01 ;{ }^{* * *} p<0.001\right)$

their $\mathrm{T}$ cell responses against the individual candidate peptides in IFNY catch assays 14 days later. The results revealed that NY-BR-1 $1_{1241-1249}$, the peptide with the highest binding affinity to the $\mathrm{D}^{\mathrm{b}}$ molecule, stimulated IFNY responses by $\mathrm{CD}^{+} \mathrm{T}$ cells in all three mice immunized (Fig. 5a). Thus, immunization of HLA-DR4tg mice with Ad.NY-BR-1 as global NY-BR-1-specific antigen induced $\mathrm{CD}^{+} \mathrm{T}$ cell responses against NY-BR-1 $1_{1241-1249}$, showing that this peptide represented a natural CTL epitope in these mice. Interestingly, the same peptide stimulated also $\mathrm{CD}^{+}{ }^{+} \mathrm{T}$ cells, most likely due to the fact that this CTL epitope (with the exception of the first amino acid) was

Table 1 NY-BR-1-specific H2-D ${ }^{b}$-restricetd CTL epitopes predicted by the SYFPEITHI database (www.syfpeithi.de)

\begin{tabular}{lll}
\hline Position & Sequence & Prediction score $\left(D^{b}\right)$ \\
\hline NY-BR-1 ${ }_{25-33}$ & WYTSNDSYI & 24 \\
NY-BR-1 $1241-1249$ & STIYNNEVL & 26 \\
NY-BR-1 160-468 $_{\text {NY-BR-1 }}$ 1092-1100 & KASANDQRF & 24 \\
\hline
\end{tabular}

located within the HLA-DR4-restricted T cell epitope NYBR-1 $1_{1242-1256}$ (Additional file 1: Figure S3).

Next, we made use of a fluorochrome-conjugated H2$\mathrm{D}^{\mathrm{b}}$ dextramer displaying the newly identified CTL epitope enabling us to detect NY-BR-1 $1_{1241-1249}$-specific CD8 ${ }^{+} \mathrm{T}$ cells directly ex vivo. Using this multimer, we found $0.3 \% \pm 0.1 \% \mathrm{CD}^{+}$dextramer $^{+}$spleen cells in HLA-DR4tg mice immunized with Ad.NY-BR1, as compared to $0.036 \% \pm 0.005 \%$ in spleens of control mice. In contrast, incubation with a control dextramer displaying an irrelevant epitope did not stain spleen cells at all, thus proving specificity of our dextramer (not shown). When gating on $\mathrm{CD}^{+}{ }^{-} \mathrm{CD} 14^{-}$splenocytes, we detected 3.0 to $3.8 \% \mathrm{CD}^{+}$ dextramer ${ }^{+} \mathrm{T}$ cells among spleen cells of mice immunized with Ad.NY-BR-1, whereas among spleen cells from control mice or from immunized mice treated with control dextramer only 0.18 and $0.29 \%$, of the cells appeared double positive, respectively (Fig. $5 \mathrm{c}$ ). A representative set of dot plots showing NY-BR-1-specific CTLs among spleen cells of a control mouse and an immunized mouse is depicted in Fig. 5b. 

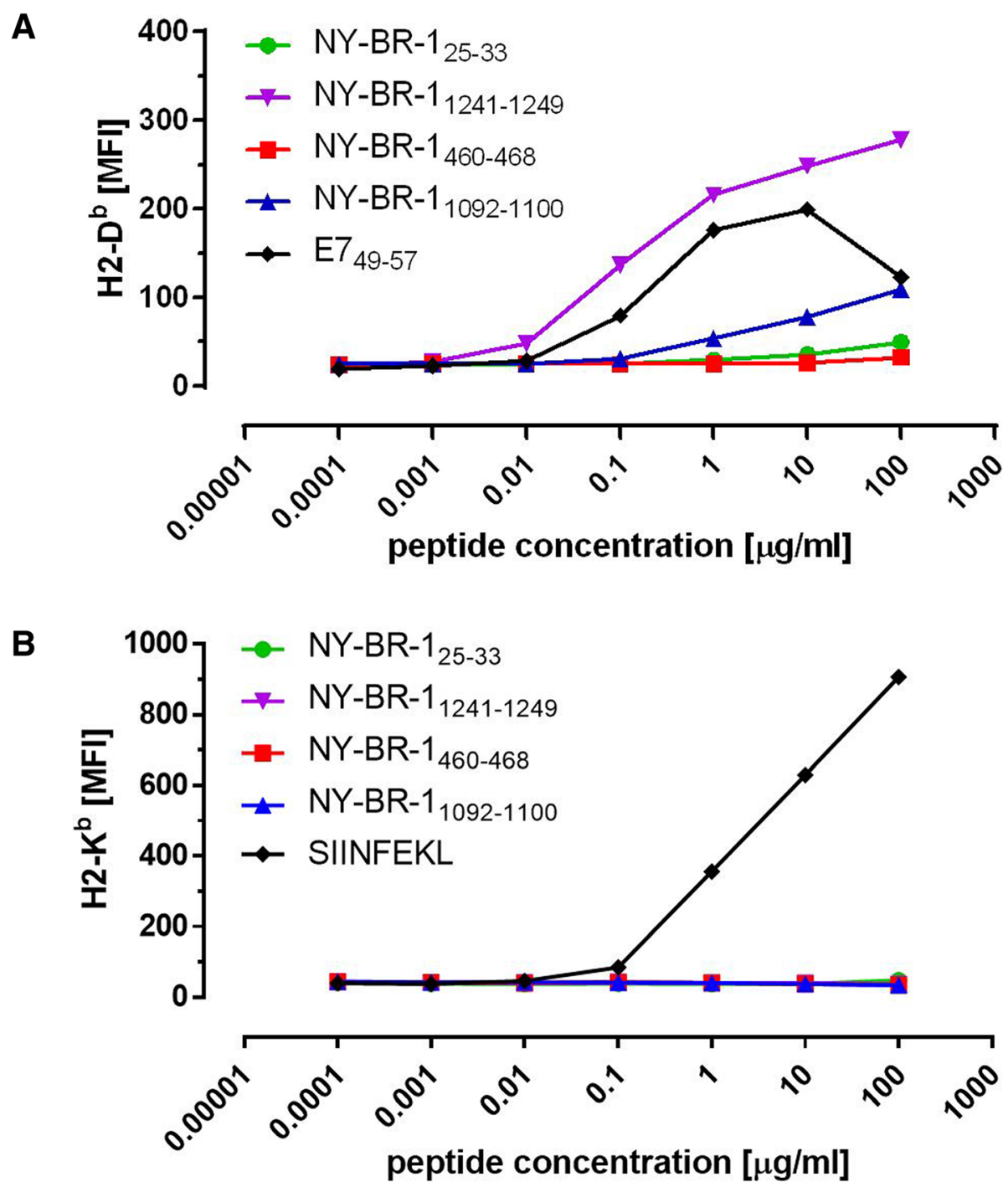

Fig. 4 Peptide binding affinities of putative $\mathrm{H}_{2}{ }^{\mathrm{b}}$-restricted NY-BR-1-specific CTL epitopes. Peptide binding affinity of putative $\mathrm{CTL}$ epitopes to $\mathrm{H} 2$ $\mathrm{K}^{\mathrm{b}}$ and $-\mathrm{D}^{\mathrm{b}}$ molecules was tested on RMA-S cells using $\mathbf{a} \mathrm{H} 2-\mathrm{D}^{\mathrm{b}}$-specific monoclonal antibody $\mathrm{B} 22.249$ or $\mathbf{b} \mathrm{H} 2-\mathrm{K}^{\mathrm{b}}$-specific monoclonal antibody E3-25. Surface expression of MHC I molecules stabilized by external addition of synthetic candidate epitopes was measured by flow cytometry to provide an estimate of peptide binding affinity. The H2-D -restricted E7-specific epitope E7 $49-57$ and the H2- $\mathrm{K}^{\mathrm{b}}$-restricted OVA-specific epitope $\mathrm{OVA}_{257-264}$ served as positive controls

Immunization with Ad.NY-BR-1 mediates partial tumor protection in HLA-DR4tg mice and induces accumulation of TAMs with reduced expression of $\mathrm{CxCl10}$

Having observed that injection of Ad.NY-BR-1 induced NY-BR-1-specific $\mathrm{T}$ cell responses within the $\mathrm{CD}^{+}$and the $\mathrm{CD}^{+} \mathrm{T}$ cell compartments, we tested if this immunization approach could mediate protection against outgrowth of NY-BR-1 expressing tumors. Thus, HLA-DR4tg mice were immunized with Ad5.NY-BR-1 or with empty virus as control. Fourteen days later, EONY\#17 cells were injected subcutaneously and tumor development was monitored for 30 days (Fig. 6a). Mice immunized with Ad5.NY-BR-1 showed decelerated tumor growth as compared to the control group (Fig. 6b). Likewise, the average tumor size and weight were significantly reduced in the group of Ad.NY-BR-1-injected mice as compared to the control values (Fig. 6c). Notably, the comparatively smaller EONY\#17 tumors of Ad.NY-BR-1 immunized mice contained a higher proportion of TAMs than the tumors derived from unprotected mice (Fig. 6d). Although the proportion of HLA-DR4 expressing TAMs was independent from the vaccine applied (Fig. 6e), the extent of HLA-DR4 surface expression was significantly increased on TAMs selectively after NY-BR-1-specific immunization (Fig. 6f). This data points towards a M1-like TAM phenotype. However, expression of the 


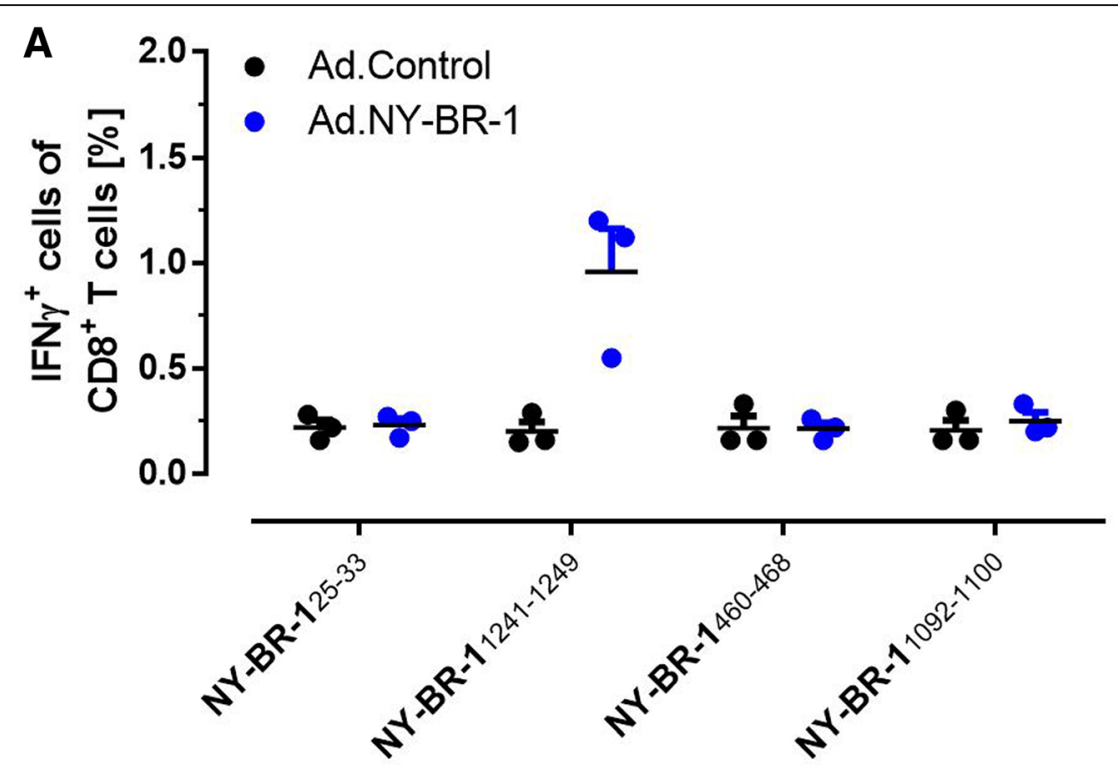

B

C
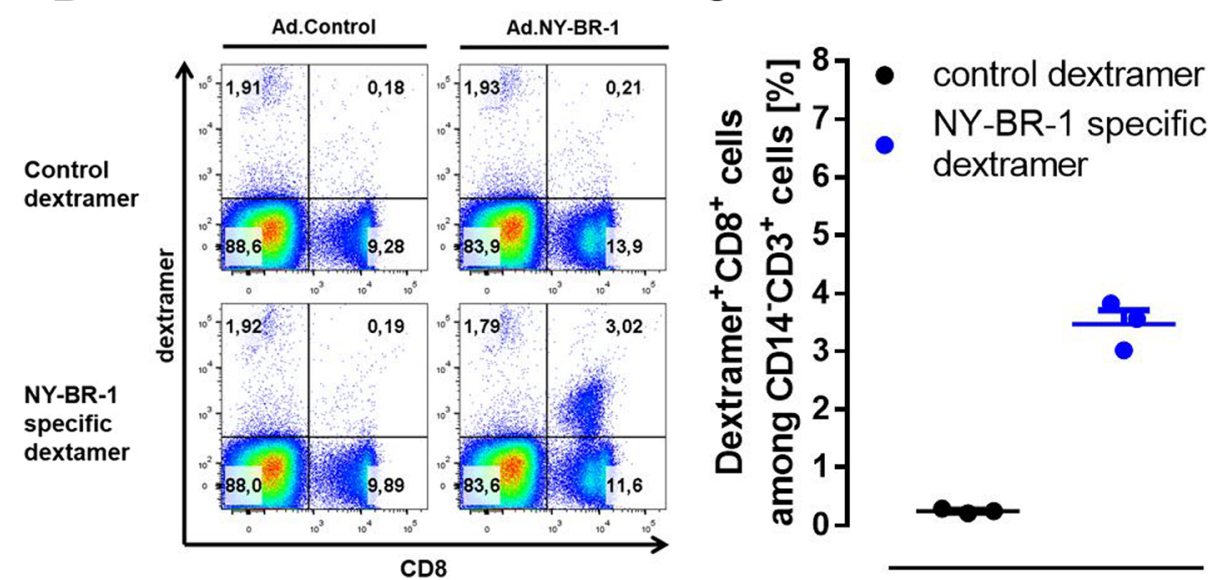

Fig. 5 NY-BR-1 $1241-1249$ is a natural H2-D ${ }^{\text {b}}$-restricted $C T L$ epitope. HLA-DRB1*0401tg mice were immunized i.p. either with $5 \times 10^{8}$ pfu Ad.NY-BR-1 $(n=3)$ or with $5 \times 10^{8} \mathrm{pfu} \mathrm{Ad}$. Control $(n=3)$ and splenocytes were harvested 14 days post immunization. a Splenocytes were incubated overnight with $5 \mu \mathrm{g} / \mathrm{mL}$ of synthetic peptides representing predicted NY-BR-1 epitopes. IFNY secreting CD8 ${ }^{+}$T cells were analyzed by IFNY catch assay and the percentage of $C D 8^{+} T$ cells secreting IFNy is depicted. Immunization with Ad.NY-BR-1 resulted in CD $8^{+} T$ cells reactive against peptides NY-BR-1 1241-1249. $\mathbf{b}$ and $\mathbf{c}$ Splenocytes from immunized mice were stained with fluorescently labelled H2-D ${ }^{\mathrm{b}}$ dextramers loaded with NYBR-1 1241-1249 (NY-BR-1-specific dextramer) or HPV 16 E7 $49-57$ (control dextramer). b Proportion of dextramer ${ }^{+} \mathrm{CD}^{+} \mathrm{T}$ cells among viable $\mathrm{CD}_{14} \mathrm{CD}^{+}$splenocytes from control mice (left panel) or from an Ad.NY-BR-1 immunized mice (right panel). c Representative dot plot depicting the proportion of dextramer ${ }^{+} \mathrm{CD} 8^{+} \mathrm{T}$ cells among viable $\mathrm{CD} 14^{-} \mathrm{CD}^{+}$splenocytes from a control mouse (left panel) or from an Ad.NY-BR-1 immunized mouse (right panel)

classical M1 marker Cxcl10 was down-regulated (Fig. 6h) and expression of M2-associated genes appeared unaltered (Fig. 6g).

Thus, immunization with replication-deficient, NYBR-1-encoding adenovirus had a suppressive, though not fully inhibitory effect on outgrowth of EONY\#17derived tumors and promoted accumulation of TAMs with enhanced HLA-DR4 surface expression, accompanied by decreased expression of the M1-associated marker Cxcl10.

\section{Discussion}

The current paper presents the first NY-BR1 expressing tumor model based on ectopic transplantation of the C57BL/6-derived mammary adenocarcinoma cell line EO771, stably transfected with a NY-BR-1-encoding expression vector, onto H2-compatible HLA-DR4tg mice. As NY-BR-1 represents a xeno-antigen in mice, it was not unexpected that the transplanted NY-BR-1 expressing tumor cells showed immunogenic potential promoting intra-tumoral $\mathrm{CD}^{+} \mathrm{T}$ cell infiltration and delayed 


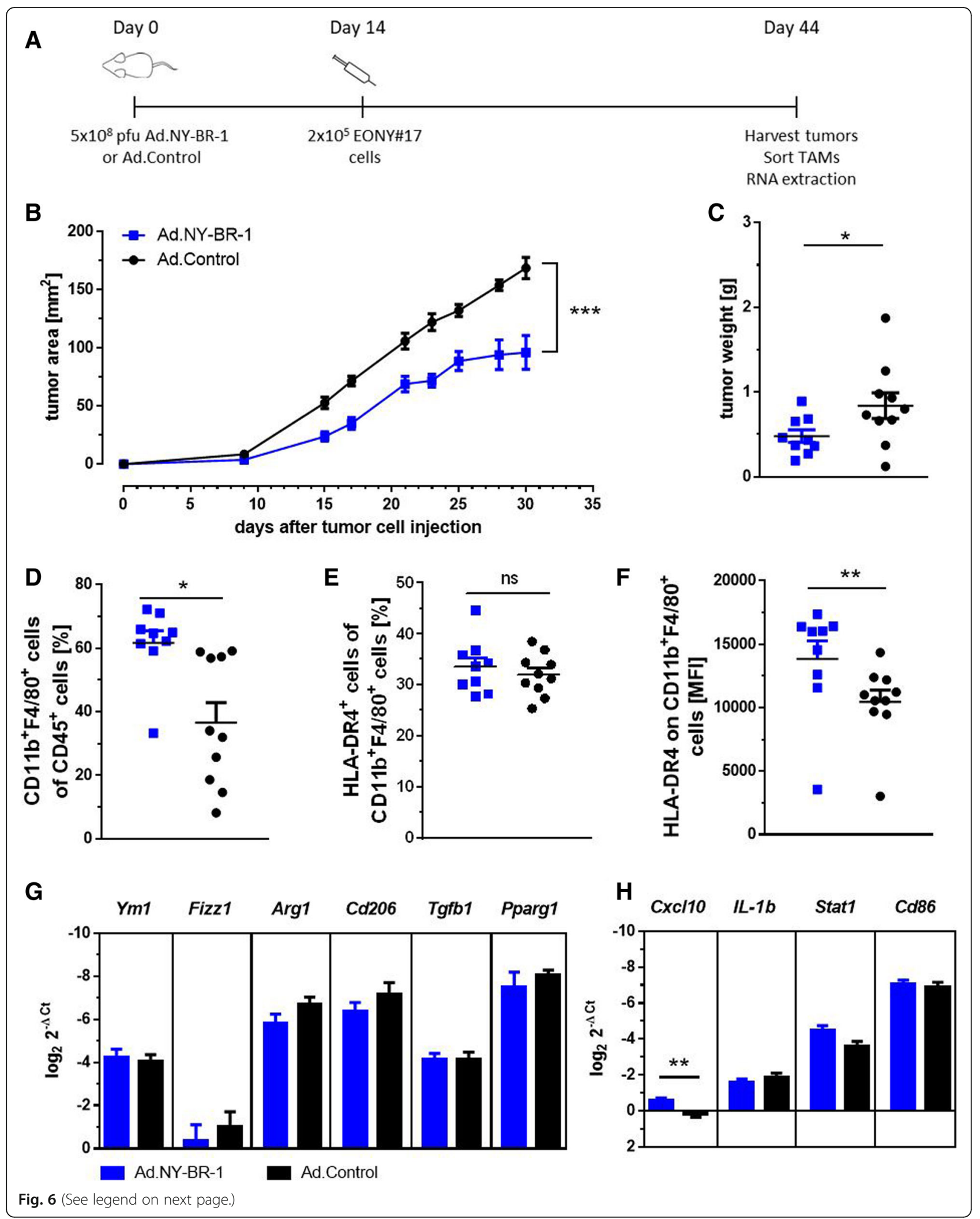




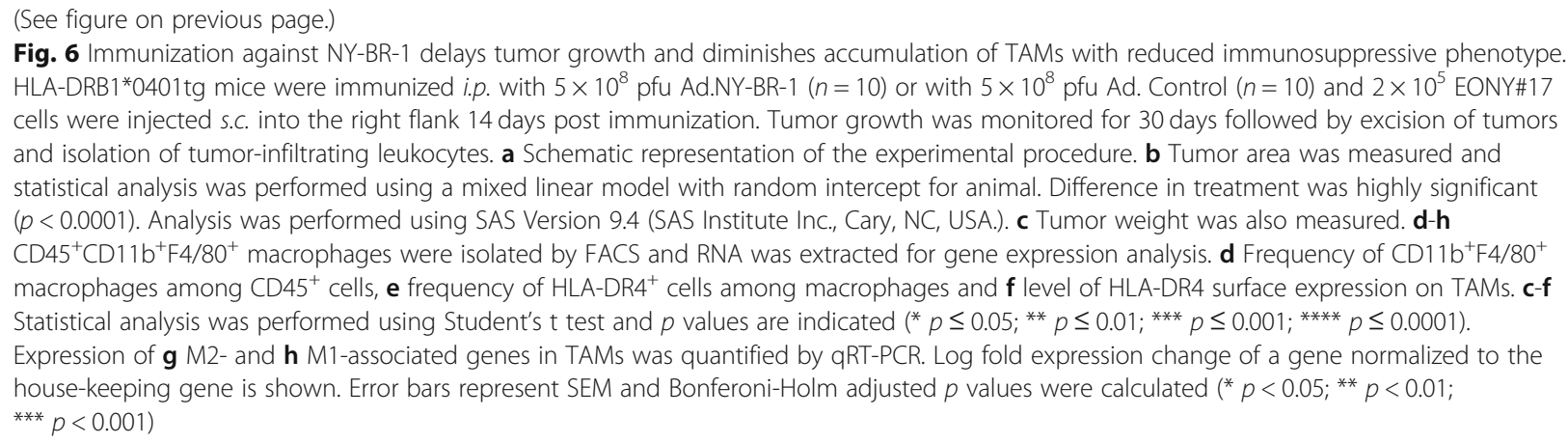

tumor outgrowth. In fact, various tumor models based on xeno-antigens have been described. The most common ones use chicken ovalbumin (OVA) as target antigen, for example, in tumor models of melanoma [20], lymphoma [21] or breast cancer [22]. In some of these examples, OVA expressing transfectants showed delayed tumor growth compared to the parental tumor cell line in vivo [23-25] as observed in our NY-BR-1 expressing model, although OVA expressing tumor models without effects on tumor outgrowth have been described as well [26]. In our system, clone EONY\#17 showing intermediate NY-BR-1 expression gave rise to tumors in all mice transplanted, providing the basis for the performance of tumor protection experiments. Immunization with recombinant adenovirus induced NY-BR-1-specific CTL as well as $\mathrm{CD}^{+} \mathrm{T}$ cell responses and reduced outgrowth of the NY-BR-1 expressing tumor cell line EONY\#17 in DR4tg mice. Optimization of the immunization protocol, for example by inclusion of adjuvants such as CpGs or antibodies against checkpoint inhibitors in combination with adoptive $T$ cell transfer [27-29], might further improve this protective effect, providing the basis for preclinical immunotherapy studies in this NY-BR-1 expressing tumor model.

In our study we identified the first $\mathrm{H} 2-\mathrm{D}^{\mathrm{b}}$-restricted, NY-BR-1-specifc CTL epitope NY-BR-1 $1241-1249$, almost entirely embedded within the HLA-DR4-restricted epitope NY-BR-1 $1242-1256$, recently identified by us [14]. Thus, immunization experiments using constructs or synthetic peptides encompassing a minimal stretch of 16 amino acids should enable simultaneous analysis of NYBR-1-specifc CD8 ${ }^{+}$CTL and HLA-DR4-restricted CD4 ${ }^{+}$ $\mathrm{T}$ cell responses in this mouse strain. Current HLAtg mouse strains are often engineered to lack expression of endogenous MHC molecules to prevent interference between $\mathrm{T}$ cell responses that are restricted by the transgenic HLA-molecule and endogenous $\mathrm{H} 2$ molecules respectively [30, 31]. In fact, EO-NY-derived $\beta_{2}$ m knockout variants have been established [17] that could be used as parental cell lines to generate stable cell transfectant clones co-expressing NY-BR-1 in combination with the transgenic HLA molecule, resulting in NY-BR-1 expressing breast cancer cell lines that might allow performance of tumor protection and regression experiments in HLA-double transgenic mice co-expressing HLA-DR4 and HLA-A2 [32].

Breast cancer is known to be highly infiltrated by macrophages generally correlating with poor prognosis [33-37]. In our model we saw similar results with $\mathrm{CD} 11 \mathrm{~b}^{+} \mathrm{F} 4 / 80^{+}$macrophages representing up to $70 \%$ of $\mathrm{CD} 45^{+}$immune cells within the tumor. This is reminiscent to TAM infiltration rates reported in the BALB/cderived $4 \mathrm{~T} 1$ breast tumor model where $\mathrm{CD} 11 \mathrm{~b}^{+}$cells constituted up to $86 \%$ of tumor infiltrating leukocytes [38]. Performing detailed gene and protein expression analyses we found that the $\mathrm{CD} 11 \mathrm{~b}^{+} \mathrm{F} 4 / 80^{+}$immune cell population in NY-BR-1 expressing tumors showed enhanced expression of both, certain M1 markers genes as well as M2-associated genes. In fact, macrophages showing overlapping phenotypes thus representing neither M1 nor M2, have been described in a murine breast cancer model [39], possibly explaining the heterogenic gene expression pattern observed among TAMs in our tumor model. Alternatively, M1- and M2-like TAMs might be distributed differentially within the tumor tissue, depending on local oxygen supply with M1 accumulating preferentially in normoxic tumor areas, whereas M2-like TAMs could occur mainly at hypoxic sites [40]. We cannot judge which of these explanations might actually apply to our tumor model since our analysis was performed on the entire $\mathrm{CD} 11^{+} \mathrm{F} 4 / 80^{+}$myeloid population and not on isolated M1/M2 subpopulations. Tumor antigen-specific immunization with Ad.NYBR1 induced TAMs showing upregulated HLA-DR4 surface expression levels pointing towards a possible M1-like phenotype, likely due to the induction of an IFN $\gamma$-producing Th1 response. As immunization with Ad.NY-BR-1 induced NY-BR-1-specific $\mathrm{CD}^{+} \mathrm{T}$ cells in EONY\#17 tumor- bearing mice and since tumor antigen-specific $\mathrm{CD}^{+} \mathrm{T}$ cells have been reported to stimulate upregulation of MHC II expression on TAMs in the tumor microenvironment $[41,42]$, this might explain why the 
TAMs in the EONY tumors of immunized mice showed preferential expression of M1-associated markers as compared to TAMs from parental tumors.

\section{Conclusion}

In summary, we established a NY-BR-1 expressing tumor model in HLA-DR4tg mice and introduce the first NY-BR1-specific, $\mathrm{H} 2-\mathrm{D}^{\mathrm{b}}$-resctricted $\mathrm{CD} 8^{+} \mathrm{T}$ cell epitope, thus allowing investigation of NY-BR-1 as a target for therapeutic vaccination approaches against breast cancer in vivo.

\section{Additional file}

Additional file 1: Table S1. Antibodies used for FACS analysis. Table S2. Primers used for qPCR. Figure S1. Detection of NY-BR-1 expression in EO771/NY-BR-1 transfectants. Figure S2. NY-BR-1 expression does not affect the viability of EO771 transfectant clones in vitro. Figure S3. H2-Db restricted epitope NY-BR-11241-1249 activates CD4+ T cells. (PDF 480 kb)

\section{Abbreviations}

Ad.NY-BR-1: Adenoviral vector coding for NY-BR-1; C57BL/6: Mouse strain; CD: Cluster of differentiation; CTL: Cytotoxic T lymphocyte; EO771: Murine breast cancer cell line; EONY\#9: Clone \#9 of NY-BR-1 stably transfected EO771 cells; HLA-DR4tg: HLA-DR4 transgenic; NY-BR-1: Breast cancer antigen 1; NY-BR-1 1242-1256: NY-BR-1 epitope comprising amino acid 1242-1256; TAMs: Tumor-associated macrophages

\section{Acknowledgements}

We thank Elke Dickes for technical assistance, Dr. Noemi Bender (DKFZ) for helpful advice regarding PEC isolation, Ulrike Träger (DKFZ) for providing antibodies, and Prof. Günter Hämmerling (DKFZ) for RMA-S cells and hybridoma supernatants. We gratefully acknowledge the help of the FACS core facility of the DKFZ in FACS sorting and analysis as well as the support by the Center for Preclinical Research at the DKFZ for animal care taking.

\section{Authors' contributions}

WO and SBE designed the study; KD generated the NY-BR-1 expressing cell line; MV identified the CTL epitope; KD and DE performed the in vivo experiments and analyzed the data; KMD and AH supported the design of transplantation experiments; AKS performed and interpreted the statistical analysis; AH and MF supported multi-color FACS experiments; DJ and IZ provided expertise on protein analysis; WO, KD and SBE wrote the manuscript. All authors read and approved the final manuscript.

\section{Authors' information}

DE and MV have performed experiments during their affiliation with the Research Group GMP \& T Cell Therapy at the DKFZ. Their present affiliation is at BioNTech and Mainz University.

\section{Funding}

DE and KD were supported by a fellowship from the Helmholtz International Graduate School for Cancer Research. The funding source had no role in the study design, data collection or analyses, the decision to publish, or the preparation of this manuscript.

\section{Availability of data and materials}

All data generated or analyzed during the current study are available from the corresponding author on reasonable request.

\section{Ethics approval and consent to participate}

The physiological interactions between T cells and tumor-associated macrophages can only be investigated within the mammalian animal model, as it provides a complete immune system including the entirety of its complex interactions. Still, performance of the animal experiments followed the $3 R$ principle, in order to minimize the number of animals recruited for the experiments and to reduce their burden.
The mice were housed and treated at the DKFZ animal facility. Animal experiments were approved by the District Government

(Regierungspräsidium Karlsruhe) in Karlsruhe, Germany (approval ID 359158.81/G172-12).

\section{Consent for publication}

Not applicable.

\section{Competing interests}

The authors declare that they have no competing interests.

\section{Author details}

${ }^{1}$ Research Group GMP \& T Cell Therapy, German Cancer Research Center (DKFZ), Heidelberg, Germany. ${ }^{2}$ Division of Virology, Innsbruck Medical University, Innsbruck, Austria. ${ }^{3}$ Faculty of Biosciences, University Heidelberg, Heidelberg, Germany. ${ }^{4}$ Biopharmaceutical New Technologies (BioNTech) Corporation, Mainz, Germany. ${ }^{5}$ University Medical Center of the Johannes Gutenberg University, Mainz, Germany. ${ }^{6}$ Core Facility Tumor Models, German Cancer Research Center (DKFZ), Heidelberg, Germany. ' Department of Molecular \& Radiation Oncology, German Cancer Research Center (DKFZ), Heidelberg, Germany. ${ }^{8} \mathrm{CCU}$ Applied Tumor Immunity, German Cancer Research Center (DKFZ), Heidelberg, Germany. ${ }^{9}$ Department of Medical Oncology, National Center for Tumor Diseases (NCT) and University Hospital Heidelberg, Heidelberg, Germany. ${ }^{10}$ Institute of Immunology, Regensburg Center for Interventional Immunology (RCl), University Regensburg and University Hospital Regensburg, Regensburg, Germany. ${ }^{11}$ Department of Biostatistics, German Cancer Research Center (DKFZ), Heidelberg, Germany.

Received: 9 April 2019 Accepted: 28 August 2019

Published online: 13 September 2019

\section{References}

1. Carioli G, Malvezzi M, Rodriguez T, Bertuccio P, Negri E, La Vecchia C. Trends and predictions to 2020 in breast cancer mortality in Europe. Breast. 2017; 36:89-95.

2. Kalam K, Marwick TH. Role of cardioprotective therapy for prevention of cardiotoxicity with chemotherapy: a systematic review and meta-analysis. Eur J Cancer. 2013;49(13):2900-9.

3. Osborne CK, Schiff R. Mechanisms of endocrine resistance in breast cancer. Annu Rev Med. 2011;62:233-47.

4. Rosenberg SA, Restifo NP. Adoptive cell transfer as personalized immunotherapy for human cancer. Science. 2015;348(6230):62-8.

5. Hughes PE, Caenepeel S, Wu LC. Targeted therapy and checkpoint immunotherapy combinations for the treatment of cancer. Trends Immunol. 2016;37(7):462-76

6. Theurillat JP, Zurrer-Hardi U, Varga Z, Storz M, Probst-Hensch NM, Seifert B, Fehr MK, Fink D, Ferrone S, Pestalozzi B, et al. NY-BR-1 protein expression in breast carcinoma: a mammary gland differentiation antigen as target for cancer immunotherapy. Cancer Immunol Immunother. 2007;56(11):1723-31.

7. Seil I, Frei C, Sultmann H, Knauer SK, Engels K, Jäger E, Zatloukal K, Pfreundschuh M, Knuth A, Tseng-Chen Y, et al. The differentiation antigen NY-BR-1 is a potential target for antibody-based therapies in breast cancer. Int J Cancer. 2007;120(12):2635-42.

8. Jäger D, Karbach J, Pauligk C, Seil I, Frei C, Chen YT, Old LJ, Knuth A, Jäger E. Humoral and cellular immune responses against the breast cancer antigen NY-BR-1: definition of two HLA-A2 restricted peptide epitopes. Cancer Immun. 2005;5:11.

9. Wang W, Epler J, Salazar LG, Riddell SR. Recognition of breast cancer cells by CD8+ cytotoxic T-cell clones specific for NY-BR-1. Cancer Res. 2006; 66(13):6826-33.

10. Neefjes J, Ovaa H. A peptide's perspective on antigen presentation to the immune system. Nat Chem Biol. 2013;9(12):769-75.

11. Bossi G, Griffiths GM. CTL secretory lysosomes: biogenesis and secretion of a harmful organelle. Semin Immunol. 2005;17(1):87-94.

12. Kennedy R, Celis E. Multiple roles for CD4+ T cells in anti-tumor immune responses. Immunol Rev. 2008;222:129-44.

13. Kreiter $S$, Vormehr $M$, van de Roemer N, Diken $M$, Lower $M$, Diekmann J Boegel S, Schrors B, Vascotto F, Castle JC, et al. Mutant MHC class II epitopes drive therapeutic immune responses to cancer. Nature. 2015; 520(7549):692-6. 
14. Gardyan A, Osen W, Zörnig I, Podola L, Agarwal M, Aulmann S, Ruggiero $\mathrm{E}$, Schmidt M, Halama N, Leuchs B, et al. Identification of NYBR-1-specific CD4+ T cell epitopes using HLA-transgenic mice. Int J Cancer. 2015;136(11):2588-97.

15. Ito K, Bian HJ, Molina M, Han J, Magram J, Saar E, Belunis C, Bolin DR, Arceo R, Campbell R, et al. HLA-DR4-IE chimeric class II transgenic, murine class IIdeficient mice are susceptible to experimental allergic encephalomyelitis. J Exp Med. 1996;183(6):2635-44.

16. Ohlschlager P, Osen W, Dell K, Faath S, Garcea RL, Jochmus I, Muller M, Pawlita M, Schafer K, Sehr P, et al. Human papillomavirus type 16 L1 capsomeres induce L1-specific cytotoxic T lymphocytes and tumor regression in C57BL/6 mice. J Virol. 2003;77(8):4635-45.

17. Das K, Eisel D, Lenkl C, Goyal A, Diederichs S, Dickes E, Osen W, Eichmüller SB. Generation of murine tumor cell lines deficient in MHC molecule surface expression using the CRISPR/Cas9 system. PLoS One. 2017;12(3):e0174077.

18. Biswas SK, Mantovani A. Macrophage plasticity and interaction with lymphocyte subsets: cancer as a paradigm. Nat Immunol. 2010;11(10):889-96.

19. Rammensee H, Bachmann J, Emmerich NP, Bachor OA, Stevanovic S. SYFPEITHI: database for MHC ligands and peptide motifs. Immunogenetics. 1999;50(3-4):213-9.

20. Dobrzanski MJ, Reome JB, Dutton RW. Therapeutic effects of tumor-reactive type 1 and type 2 CD8+ T cell subpopulations in established pulmonary metastases. J Immunol. 1999;162(11):6671-80.

21. Moore MW, Carbone FR, Bevan MJ. Introduction of soluble protein into the class I pathway of antigen processing and presentation. Cell. 1988;54(6):777-85.

22. Engelhardt John J, Boldajipour B, Beemiller P, Pandurangi P, Sorensen C, Werb Z, Egeblad M, Krummel Matthew F. Marginating dendritic cells of the tumor microenvironment cross-present tumor antigens and stably engage tumor-specific T cells. Cancer Cell. 2012;21(3):402-17.

23. Gottschalk S, Yu F, Ji M, Kakarla S, Song XT. A vaccine that co-targets tumor cells and cancer associated fibroblasts results in enhanced antitumor activity by inducing antigen spreading. PLoS One. 2013;8(12):e82658.

24. Ramsbottom KM, Sacirbegovic F, Hawkins ED, Kallies A, Belz GT, Van Ham V, Haynes NM, Durrant MJ, Humbert PO, Russell SM, et al. Lethal giant larvae-1 deficiency enhances the CD8(+) effector T-cell response to antigen challenge in vivo. Immunol Cell Biol. 2016:94(3):306-11.

25. Gilfillan S, Chan CJ, Cella M, Haynes NM, Rapaport AS, Boles KS, Andrews DM, Smyth MJ, Colonna M. DNAM-1 promotes activation of cytotoxic lymphocytes by nonprofessional antigen-presenting cells and tumors. J Exp Med. 2008;205(13):2965-73.

26. Nelson DJ, Mukherjee S, Bundell C, Fisher S, van Hagen D, Robinson B. Tumor progression despite efficient tumor antigen cross-presentation and effective "arming" of tumor antigen-specific CTL. J Immunol. 2001;166(9):5557-66.

27. Kohlmeyer J, Cron M, Landsberg J, Bald T, Renn M, Mikus S, Bondong S, Wikasari D, Gaffal E, Hartmann G, et al. Complete regression of advanced primary and metastatic mouse melanomas following combination chemoimmunotherapy. Cancer Res. 2009;69(15):6265-74.

28. Pilon-Thomas S, Mackay A, Vohra N, Mulé JJ. Blockade of programmed death ligand 1 enhances the therapeutic efficacy of combination immunotherapy against melanoma. J Immunol. 2010;184(7):3442-9.

29. Mahvi DA, Meyers JV, Tatar AJ, Contreras A, Suresh M, Leverson GE, Sen S, Cho CS. CTLA-4 blockade plus adoptive T cell transfer promotes optimal melanoma immunity in mice. J Immunother (Hagerstown, Md: 1997). 2015;38(2):54-61.

30. Perarnau B, Saron MF, Reina San Martin B, Bervas N, Ong H, Soloski MJ, Smith AG, Ure JM, Gairin JE, Lemonnier FA. Single H2Kb, H2Db and double $\mathrm{H} 2 \mathrm{KbDb}$ knockout mice: peripheral CD8+ T cell repertoire and antilymphocytic choriomeningitis virus cytolytic responses. Eur J Immunol. 1999;29(4):1243-52.

31. Cheuk E, D'Souza C, Hu N, Liu Y, Lang H, Chamberlain JW. Human MHC class I transgenic mice deficient for $\mathrm{H} 2$ class I expression facilitate identification and characterization of new HLA class I-restricted viral T cell epitopes. J Immunol. 2002;169(10):5571-80.

32. Majji S, Wijayalath W, Shashikumar S, Pow-Sang L, Villasante E, Brumeanu TD, Casares S. Differential effect of HLA class-I versus class-II transgenes on human T and B cell reconstitution and function in NRG mice. Sci Rep. 2016;6:28093.

33. Zhang Y, Cheng S, Zhang M, Zhen L, Pang D, Zhang Q, Li Z. Highinfiltration of tumor-associated macrophages predicts unfavorable clinical outcome for node-negative breast cancer. PLoS One. 2013;8(9):e76147.

34. Medrek C, Ponten F, Jirstrom $K$, Leandersson $K$. The presence of tumor associated macrophages in tumor stroma as a prognostic marker for breast cancer patients. BMC Cancer. 2012;12:306.
35. Tsutsui S, Yasuda K, Suzuki K, Tahara K, Higashi H, Era S. Macrophage infiltration and its prognostic implications in breast cancer: the relationship with VEGF expression and microvessel density. Oncol Rep. 2005;14(2):425-31.

36. Mahmoud SM, Lee AH, Paish EC, Macmillan RD, Ellis IO, Green AR. Tumourinfiltrating macrophages and clinical outcome in breast cancer. J Clin Pathol. 2012;65(2):159-63.

37. Ruffell B, Au A, Rugo HS, Esserman $\sqcup$, Hwang ES, Coussens LM. Leukocyte composition of human breast cancer. Proc Natl Acad Sci. 2012;109(8):2796-801.

38. DuPre SA, Redelman D, Hunter KW Jr. The mouse mammary carcinoma 4T1: characterization of the cellular landscape of primary tumours and metastatic tumour foci. Int J Exp Pathol. 2007:88(5):351-60.

39. Torroella-Kouri M, Silvera R, Rodriguez D, Caso R, Shatry A, Opiela S, Ilkovitch D, Schwendener RA, Iragavarapu-Charyulu V, Cardentey Y, et al. Identification of a subpopulation of macrophages in mammary tumorbearing mice that are neither M1 nor $\mathrm{M} 2$ and are less differentiated. Cancer Res. 2009;69(11):4800-9.

40. Movahedi K, Laoui D, Gysemans C, Baeten M, Stange G, Van den Bossche J, Mack M, Pipeleers D, In't Veld P, De Baetselier P, et al. Different tumor microenvironments contain functionally distinct subsets of macrophages derived from Ly6C(high) monocytes. Cancer Res. 2010;70(14):5728-39.

41. Haabeth OA, Lorvik KB, Hammarstrom C, Donaldson IM, Haraldsen G, Bogen B, Corthay A. Inflammation driven by tumour-specific Th1 cells protects against B-cell cancer. Nat Commun. 2011;2:240.

42. Corthay A, Lundin KU, Lorvik KB, Hofgaard PO, Bogen B. Secretion of tumorspecific antigen by myeloma cells is required for cancer immunosurveillance by CD4+ T cells. Cancer Res. 2009;69(14):5901-7.

\section{Publisher's Note}

Springer Nature remains neutral with regard to jurisdictional claims in published maps and institutional affiliations.

Ready to submit your research? Choose BMC and benefit from:

- fast, convenient online submission

- thorough peer review by experienced researchers in your field

- rapid publication on acceptance

- support for research data, including large and complex data types

- gold Open Access which fosters wider collaboration and increased citations

- maximum visibility for your research: over $100 \mathrm{M}$ website views per year

At $\mathrm{BMC}$, research is always in progress.

Learn more biomedcentral.com/submissions 